\title{
Peripheral Metabolic Effects of Endocannabinoids and Cannabinoid Receptor Blockade
}

\author{
Stefan Engeli \\ Franz Volhard Clinical Research Center at the Experimental and Clinical Research Center, Charité - Campus Buch, Berlin, Germany
}

\section{Key Words}

Anandamide - 2-Arachidonoyl glycerol - CB1 receptors . Adipose tissue · Liver · Rimonabant

\section{Summary}

The endocannabinoid system consists of endogenous arachidonic acid derivates that activate cannabinoid receptors. The two most prominent endocannabinoids are anandamide and 2-arachidonoyl glycerol. In obesity, increased concentrations of circulating and tissue endocannabinoid levels have been described, suggesting increased activity of the endocannabinoid system. Increased availability of endocannabinoids in obesity may over-stimulate cannabinoid receptors. Blockade of cannabinoid type 1 (CB1) receptors was the only successful clinical development of an anti-obesity drug during the last decade. Whereas blockade of CB1 receptors acutely reduces food intake, the long-term effects on metabolic regulation are more likely mediated by peripheral actions in liver, skeletal muscle, adipose tissue, and the pancreas. Lipogenic effects of $\mathrm{CB} 1$ receptor signalling in liver and adipose tissue may contribute to regional adipose tissue expansion and insulin resistance in the fatty liver. The association of circulating 2-arachidonoyl glycerol levels with decreased insulin sensitivity strongly suggests further exploration of the role of endocannabinoid signalling for insulin sensitivity in skeletal muscle, liver, and adipose tissue. A few studies have suggested a specific role for the regulation of adiponectin secretion from adipocytes by endocannabinoids, but that has to be confirmed by more experiments. Also, the potential role of CB1 receptor blockade for the stimulation of energy expenditure needs to be studied in the future. Despite the current discussion of safety issues of cannabinoid receptor blockade, these findings open a new and exciting perspective on endocannabinoids as regulators of body weight and metabolism.

\section{Endocannabinoids: Recent History of an Ancient Biological System}

Exogenous cannabinoids contained in hemp (Cannabis sativa) extracts and plant parts have been used for medical and recreational purposes for thousands of years. The principal chemical compound, $\Delta^{9}$-tetrahydrocannabinol $\left(\Delta^{9}\right.$-THC), was identified in 1964. The history of the endocannabinoid system (ECS), however, is much more recent. Milestones of endocannabinoid research are summarized in table 1. Endocannabinoids are lipophilic molecules that act as cannabinoid receptor agonists. The arachidonic acid esters $\mathrm{N}$-arachidonoyl ethanolamine (anandamide or AEA) and 2-arachidonoyl glycerol (2-AG) are the two most important and mostly studied endocannabinoids.

Endocannabinoids are not stored in cells but are acutely produced 'on demand' if intracellular $\mathrm{Ca}^{2+}$ concentrations rise. In neurons, neurotransmitter activation may stimulate endocannabinoid synthesis and release by membrane depolarization. In the brain, endocannabinoids released from postsynaptic neurons may act as retrograde signals to modulate presynaptic neurotransmitter secretion. Mechanisms of endocannabinoid synthesis in peripheral, non-neural cells have not been studied in detail, but the enzymes are most likely the same as in neurons, and thus the role of intracellular $\mathrm{Ca}^{2+}$ as a signal might be the same. Metabolic stress or cellular damage also leads to endocannabinoid synthesis. Endocannabinoids are rapidly degraded by intracellular enzymes such as fatty acid amide hydrolase (FAAH) and monoglyceride lipase (MGL).

The cannabinoid receptors (CB1 and CB2) are encoded by two different genes on human chromosomes 6q14-q15 (CNR1) and 1p36.11 (CNR2). Both are seven-transmembrane domain $\mathrm{G}_{\mathrm{i} / \mathrm{o}}$ protein-coupled receptors, and typical intracellular events following cannabinoid receptor activation are decreased cyclic adenosine monophosphate (cAMP) synthesis, increased $\mathrm{K}^{+}$efflux, and decreased $\mathrm{Ca}^{2+}$ influx [26]. CB1 is highly expressed in most brain regions, lower expression levels

\begin{tabular}{|c|c|}
\hline KARGER & (c) 2008 S. Karger GmbH, Freiburg \\
\hline $\begin{array}{l}\text { Fax +49 } 7614520714 \\
\text { E-mail Information@Karger.de } \\
\text { www.karger.com }\end{array}$ & $\begin{array}{l}\text { Accessible online at: } \\
\text { www.karger.com/ofa }\end{array}$ \\
\hline
\end{tabular}

Stefan Engeli, MD

Franz Volhard Clinical Research Center at the Experimental and Clinical Research Center Charité - Campus Buch

Lindenberger Weg 80,13125 Berlin, Germany

Tel. +49 30 9417-1372, Fax -2265

E-mail stefan.engeli@charite.de 
Table 1. Milestones of endocannabinoid research related to metabolic regulation

\begin{tabular}{|c|c|}
\hline Year & Discovery \\
\hline 1964 & Identification of $\Delta^{9}$-THC [1] \\
\hline 1988 & Identification of cannabinoid binding sites in the brain [2] \\
\hline 1990 & Cloning of rat $\mathrm{CB} 1$ receptors [3] \\
\hline 1991 & Cloning of human CB1 receptors [4] \\
\hline 1992 & Identification of anandamide as the first endocannabinoid [5] \\
\hline 1993 & Cloning of human peripheral $\mathrm{CB} 2$ receptors $[6]$ \\
\hline 1994 & Development of rimonabant as the first CB1 antagonist [7] \\
\hline 1995 & Identification of 2-AG as a second endocannabinoid [8] \\
\hline 1996 & Identification of FAAH as the anandamide degrading enzyme [9] \\
\hline 1998 & First description of weight reduction by rimonabant [10] \\
\hline 1999 & Genetic inactivation of CB1 receptors (CB1-/- mice) $[11,12]$ \\
\hline 2001 & $\begin{array}{l}\text { Discovery of endocannabinoids as retrograde neurotransmitters } \\
\text { [13] }\end{array}$ \\
\hline 2003 & $\begin{array}{l}\text { First finding of peripheral metabolic effects of endocannabinoids } \\
{[14,15]} \\
\text { Cloning of DAGL as } 2-A G \text { synthesizing enzymes }\end{array}$ \\
\hline 2004 & $\begin{array}{l}\text { Identification of NAPE-PLD as anandamide synthesizing enzyme } \\
{[17]}\end{array}$ \\
\hline 2005 & $\begin{array}{l}\text { First publications of RIO (Rimonabant in Obesity) Trials }[18,19] \\
\text { Protection of CB1-/- mice from liver steatosis }[20]\end{array}$ \\
\hline 2006 & $\begin{array}{l}\text { Activation of the ECS in human visceral obesity }[21,22] \\
\text { Further publications of RIO (Rimonabant in Obesity) Trials [23, } \\
24] \\
\text { EMEA approves rimonabant as an anti-obesity drug in Europe }\end{array}$ \\
\hline 2007 & $\begin{array}{l}\text { Publication of a rimonabant mortality study in obese diabetic rats } \\
{[25]} \\
\text { FDA advisory panel voted against approval of rimonabant in the } \\
\text { USA }\end{array}$ \\
\hline
\end{tabular}

are found in several peripheral tissues. CB2 is predominantly localized on peripheral immune cells, but has recently been also localized to the brain stem [27]. Exploration of CB1 receptor-mediated effects was stimulated by the discovery of the specific inverse agonist/antagonist SR141716 (rimonabant), and the development of CB1 knockout (CB1-/-) mice. Using these tools, the physiology and pathophysiology of the ECS, as well as pharmacological means to target the ECS, have extensively been studied during the last decade [28-31]. Beside the peripheral metabolic effects of the ECS that will be described in detail in this review, mounting evidence suggests that endocannabinoid signalling plays a critical role in pathophysiological cardiovascular conditions such as hypotension with hemorrhagic shock [32] or liver cirrhosis [33], ischemic/reperfusion injury [34], acute heart failure [35], cardiovascular aging [36] and atherosclerosis progression [37].

\section{The Endocannabinoid System in Obesity}

One of the important findings related to metabolic endocannabinoid research is the fact that the ECS is inadequately activated in obesity. CB1 receptor expression is changed, and endocannabinoid levels are increased in several organs of obese animals (e.g. adipose tissue, liver, pancreas) and in adipose tissue and the circulation of obese human subjects [15, 20, 38, 39]. The mechanisms of ECS activation in obesity are not clear as yet, but pathophysiological stimulation of cannabinoid receptors may in part explain obesity-associated metabolic changes and also offers an explanation for the successful use of the CB1 receptor inverse agonist/antagonist rimonabant for weight reduction and metabolic disorders of the obese [40].

The most intriguing data came from two human studies [21, 22] that measured adipose tissue distribution by imaging techniques and insulin sensitivity or glucose tolerance by the euglycemic-hyperinsulinemic clamp technique or an oral glucose load. Of importance, both studies investigated obese subjects within a reasonable range of body weight and did not focus on morbidly obese subjects. In a comparison of lean and obese men and women with either subcutaneous or visceral adipose tissue accumulation ( $\mathrm{n}=60$ in total), $2-\mathrm{AG}$ plasma concentrations were clearly correlated with visceral adipose tissue mass, whereas obese subjects with subcutaneous adipose tissue accumulation were not different from the lean control group with regard to 2-AG plasma concentration. Anandamide was higher in women than in men, but no relationship with obesity or body fat distribution was found in this study. Furthermore, the expression of CB1 and FAAH genes in both subcutaneous and visceral adipose tissue depots were down-regulated with visceral obesity [21].

Similar findings were reported in a study of 62 well-characterized men. The men in the highest tertile of 2-AG blood levels presented with markedly increased visceral adipose tissue mass despite having nearly the same BMI compared to the lower two tertiles of plasma 2-AG. Anandamide, in contrast, was negatively correlated with visceral fat mass [22]. Both studies found correlations of increased plasma 2-AG with markers of the metabolic syndrome (e.g. free fatty acids, triglycerides, HDL cholesterol, adiponectin) and decreased insulin sensitivity as represented by enhanced glucose, and insulin responses during an oral glucose load.

\section{Rimonabant in Obesity: More to the Picture than Meets the Eye}

The Rimonabant in Obesity (RIO) program included 6,600 overweight and obese subjects in four randomized, placebocontrolled 1-year (RIO-Lipids, RIO-Diabetes) or 2-year (RIOEurope, RIO-North America) studies. All subjects were advised to reduce caloric intake by 600 calories daily throughout the placebo run-in and treatment period. The primary end point in all trials was weight reduction. Data on side effects of rimonabant can be found in the original reports [18, 19, 23, 24] and in a meta-analysis [41]. Rimonabant, $20 \mathrm{mg} /$ day, enabled patients to lose $5 \mathrm{~kg}$ of body weight and $4 \mathrm{~cm}$ of waist circumference more than patients taking placebo. Reductions of weight and waist circumference were less pronounced in dia- 
betic patients taking metformin or sulfonylureas, but still significantly larger than in the placebo group. Weight loss was accompanied by favorable changes in triglycerides $(-14 \%$ in addition to results with placebo), high-density lipoprotein (+8\%), and fasting insulin $(-4 \mu \mathrm{U} / \mathrm{ml}$ in non-diabetic patients). In nondiabetic patients, rimonabant reduced the number of patients fulfilling the National Cholesterol Education Program's Adult Treatment Panel III criteria for the metabolic syndrome by $30 \%$ more than in those taking placebo. In RIO-Lipids, rimonabant reduced small-dense low-density lipoprotein particles, and a significant reduction in insulin secretion was seen following an oral glucose load. High-sensitive C-reactive protein and adiponectin was decreased by $30 \%$ and increased by $40 \%$, respectively. In RIO-Diabetes, the absolute change of hemoglobin $\mathrm{A}_{1 \mathrm{c}}\left(\mathrm{Hb}_{1 \mathrm{c}}\right)$ compared with placebo was $-0.7 \%$, independent of the concomitant oral hypoglycemic drug.

Metabolic changes and weight loss lasted as long as rimonabant was taken. Once patients were re-randomized to placebo after 1 year rimonabant treatment in RIO-North America, the rimonabant-related treatment effects were lost and body weight rose to the level of the ever-placebo treated group. This finding clarifies the chronic nature of obesity and obesity-associated metabolic disease. Using the placebo data as a calibrator for analysis of co-variance (ANCOVA) of the favorable changes in lipid parameters, fasting insulin, $\mathrm{HbA}_{1 \mathrm{c}}$, and adiponectin, $50 \%$ were calculated to be due to weight loss, whereas the other $50 \%$ were due to rimonabant-specific effects independent of weight loss. These calculations await experimental verification, but they suggest peripheral metabolic effects of endocannabinoids.

\section{A Closer Look on Weight Reduction by CB1 Receptor Blockade}

$\Delta^{9}$-THC is used as an adjunct treatment in HIV and cancer patients because of antiemetic and orexigenic properties [42]. Injection of anandamide into the ventromedial hypothalamus of rats increased food intake [43]. Peripheral administration of anandamide increased food intake of rats even during periods of satiety [44]. These orexigenic effects were mediated by central CB1 receptors. Hunger, satiety, and food intake are predominantly regulated in hypothalamic nuclei [45]. Imaging studies identified several brain regions with high CB1 density in humans [46], and ultrastructural analyses demonstrated presynaptic expression of CB1 receptors on many hypothalamic neurons in the mouse brain [47]. Thus, endocannabinoids may act as modulators of the main orexigenic and anorexigenic neuropeptides, as described in other brain regions and other neural functions [13]. Furthermore, other brain regions than the hypothalamus are also involved in the regulation of food intake by endocannabinoids, thus homeostatic and hedonistic mechanisms are important for the orexigenic effects of endocannabinoids [48]. Leptin, one of the main anorexigenic hormones that is secreted by adipocytes and acts via central leptin receptors, is able to reduce endocannabinoid levels in the hypothalamus [49]. Electrophysiological measurements confirmed the interactions between leptin and endocannabinoid signalling in hypothalamic neurons [50].

Confirming the pharmacological studies of endocannabinoid administration, CB1-/- mice were lean and resistant to dietinduced obesity [51]. Body weight and body fat mass of CB1-/- mice were approximately 24 and 60\% lower compared to wild-type mice. The lean phenotype was associated with changes in the balance between orexigenic and anorexigenic peptides. In CB1-/- mice, hypothalamic expression of the anorexigenic peptide corticotrophin-releasing hormone $(\mathrm{CRH})$ was increased, whereas expression of the orexigenic peptide cocaine- and amphetamine-related transcript (CART) was decreased [14]. Recent studies in mice also demonstrated that $\mathrm{CB} 1$ receptor activation increased CART expression in hypothalamic nuclei and the nucleus accumbens, again suggesting that CART is a downstream mediator of orexigenic endocannabinoid actions [52]. Similar to genetic inactivation of $\mathrm{CB} 1$ receptors, rimonabant reduced food intake and body weight in animals $[10,53]$.

Although the opposing acute effects of endocannabinoids or CB1 receptor inactivation/blockade on food intake have been well described, the regulation of long-term energy balance by the ECS is not understood. In young CB1-/- mice, decreased food intake contributed to the lean phenotype, but pair-fed older wild-type mice were heavier than CB1-/- mice [14]. Rimonabant treatment of diet-induced obese mice over 6 weeks resulted in $20 \%$ body weight reduction, but reduced food intake was only seen during the first week of treatment. Surprisingly, body weight tended to fall throughout the studies despite normalization of food intake after the first week of treatment $[53,54]$. In obese leptin-deficient mice, rimonabant also decreased body weight and food intake. Pair-feeding experiments, however, revealed that the reduction of food intake was not sufficient to reduce body weight of untreated, pair-fed obese mice [55]. Thus, reduced food intake is only a transient phenomenon of CB1 receptor blockade or genetic inactivation, and fat mass reduction must be due to additional, most likely peripheral metabolic mechanisms. Unfortunately, human studies that examined food intake during rimonabant treatment are not available. Energy expenditure studies that should be able to explain the lack of efficiency of pair-feeding to mimic rimonabant effects on body weight are also missing.

\section{The Endocannabinoid-System in Adipose Tissue}

\section{Components of the ECS in Adipose Tissue}

Human and rodent adipocytes express all genes necessary to synthesize and degrade anandamide and 2-AG [14, 38, 39, 56-58]. For example, MGL is an enzyme that was initially cloned 
from an adipocyte cDNA library because the release of the last fatty acid from the glycerol backbone is an important step in adipocyte lipolysis [59]. A special case must be made for CB2 receptors. Some authors described CB2 expression in adipocytes $[38,60]$, whereas others did not identify them in mature adipocytes $[39,56,58,61]$. Several explanations might be considered: first, anti-CB2 receptor antibodies were used in one study [60], but in the meantime it is rather clear that nearly all available antibodies against CB2 receptors are of low specificity. Second, species differences must be considered, as one study examined adipogenesis of the mouse clonal preadipocyte cell line 3T3-F442A [38], whereas most other studies used isolated mature human adipocytes. Third, the difference between isolated adipocytes and adipose tissue must be considered because in whole adipose tissue preparations several other cell types with known CB2 expression are included [62]. Thus, small quantities of CB2 mRNA in such samples do not reflect adipocyte expression but most likely originate from monocyte and lymphocyte infiltration of adipose tissue especially of obese donors [58]. Receptor binding studies revealed that only CB1 is present in membranes of isolated mature human adipocytes [56].

\section{Endocannabinoids, Adipogenesis, and PPAR}

The differentiation process during which preadipocytes change their gene expression pattern, increase in size due to triglyceride accumulation, and start to secrete adipokines is called adipogenesis. The expression of ECS genes and the synthesis of endocannabinoids increased during adipogenesis [38, 39, 58, 61, 63]. Adipogenesis itself was stimulated by synthetic cannabinoid receptor agonists and anandamide in several murine preadipocyte cell lines. Some authors suggested a direct adipogenic role of $\mathrm{CB} 1$ receptor activation [38], but a more likely explanation might be that several endocannabinoid compounds activate the master regulator of adipogenesis, $\operatorname{PPAR} \gamma$ (peroxisome proliferator-activated receptor gamma) $[64,65]$. Whereas PPAR $\gamma$ activation did not influence synthesis of endocannabinoids in immature 3T3-F442A adipocytes [38], CB1 gene expression was inhibited and FAAH gene expression was increased by PPAR $\gamma$ activation in immature in vitro differentiated human adipocytes [58]. CB1 receptor stimulation increased PPAR $\gamma$ gene expression in mouse and human adipocytes, but these data were obtained during active in vitro adipogenesis. Thus it is unclear whether a direct effect was observed or if PPAR $\gamma$ expression increased because this gene was activated during adipogenesis anyway $[38,58]$.

\section{Endocannabinoids, Lipogenesis, and Glucose Uptake in Adipocytes}

Lipogenesis is a complex biochemical process which enables adipocytes (and other cells) to store triglycerides. Lipogenesis involves both glucose and fatty acid metabolism. Glycolysis following glucose uptake provides the glycerol backbone, whereas fatty acids are transported into cells after they were cleaved from circulating triglyceride-rich lipoproteins by lipoprotein lipase (LPL) activity. In rodent adipocytes, a considerable amount of glucose is also used for de novo synthesis of fatty acids, whereas in human adipocytes this is only observed in vitro, but not in vivo under physiological situations. CB1 agonists promoted lipoprotein lipase activity in isolated mouse adipocytes [14].

A recent report described stimulation of insulin-mediated glucose uptake in murine adipocytes by anandamide via CB1 receptors that was mediated by stimulation of inducible nitric oxide synthase expression and nitric oxide formation by adipocytes [61]. In human adipocytes, CB1 activation increased basal, but not insulin-stimulated glucose uptake by stimulation of GLUT4 translocation and increased intracellular $\mathrm{Ca}^{2+}$ availability [58]. Both effects were dependent on activation of the PI3-kinase, thus CB1 and insulin receptors converge on the same pathways with respect to glucose uptake into human adipocytes. Maybe the insulin effect on glucose uptake was too strong in these experiments to allow additive effects of co-incubation with CB1 agonists.

Lipogenic effects of endocannabinoids in adipose tissue are also partly due to inhibition of AMP-activated kinase (AMPK) [66]. Indirect hints to lipogenic properties of endocannabinoids came from rimonabant studies. Here, rimonabant inhibited in vitro lipid accumulation of mouse preadipocytes [67] and induced several changes in gene expression in diet-induced obese mice that might translate to reduced adipocyte size and weight loss [54]. These gene expression studies await confirmation by physiological studies. In human subcutaneous and visceral adipocytes, however, no relationship was found between the quantity of CB1 mRNA expression and variables of either lipogenesis (triglyceride synthesis) or lipolysis (fatty acid release) [68].

\section{Endocannabinoids, Adiponectin, and Leptin}

In the RIO-Lipids trial, the increase of the insulin-sensitizing and anti-inflammatory adipokine adiponectin was calculated to be partly independent of weight loss [19]. Thus, the influence of the ECS on adiponectin was studied by some investigators. Increased adipose tissue expression and circulating levels of adiponectin were described in obese Zucker rats treated with rimonabant $[15,25]$. The same results were obtained in diet-induced obese rats, but in contrast to the obese Zucker rat model, pair-feeding revealed that the increase of adiponectin in this experiment was solely explained by weight loss due to decreased food intake [69]. In vitro, CB1 activation reduced and rimonabant stimulated adiponectin mRNA expression and secretion by murine adipocytes $[38,67,70]$. Again, this CB1-mediated effect might be related to decreased AMPK activity 


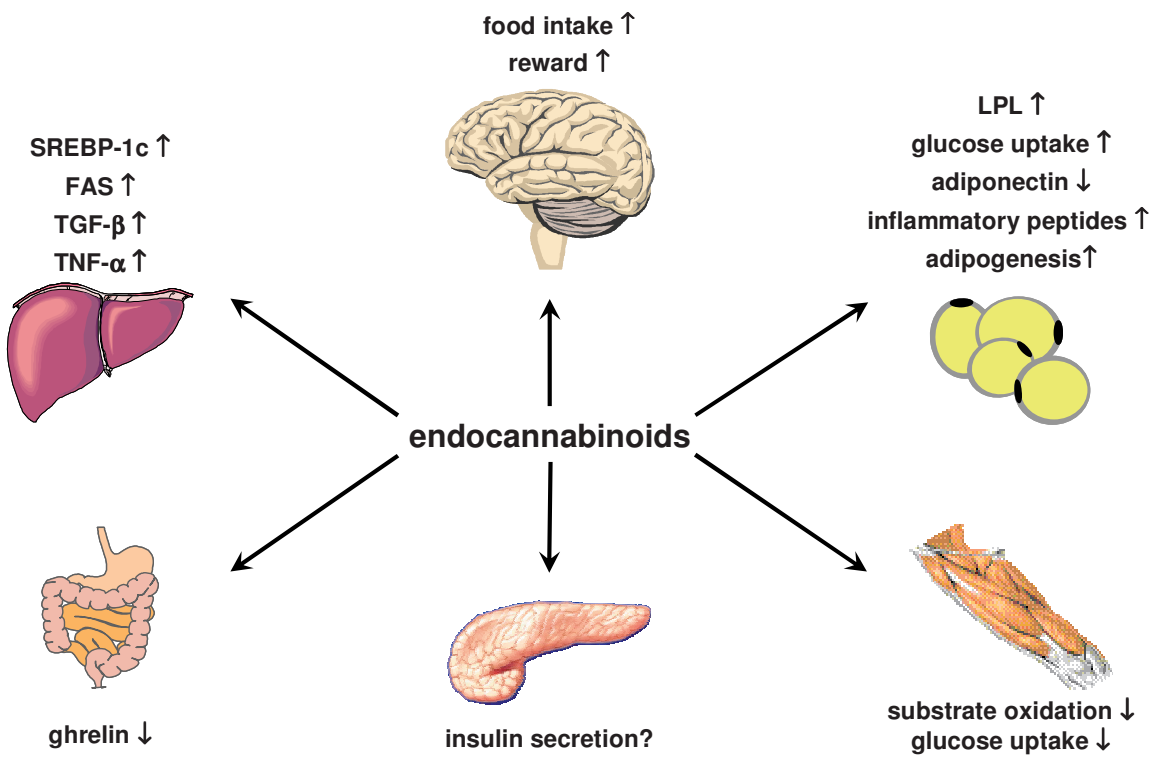

[66]. In clear contrast, however, CB1 receptor activation did not stimulate adiponectin expression in vitro in mature human adipocytes [58], and no correlation was found between CB1 expression levels and adiponectin in human adipocytes isolated from biopsy samples [68]. Leptin is another important secreted product of adipocytes. Leptin inhibits endocannabinoid synthesis, and leptin deficiency is accompanied by increased activation of the ECS in the brain and uterus $[49,71]$. The negative regulation of endocannabinoid formation by leptin has also been described in human and rodent adipocytes [38, 57]. In contrast, leptin expression was not influenced by CB1 stimulation or blockade in human primary adipocytes [58].

\section{The Endocannabinoid System in the Liver}

Although restricted in number, the most intriguing data on peripheral effects of the ECS are currently available for the liver. CB1 receptor activation stimulated lipogenesis in mouse hepatocytes via the transcription factor SREBP-1c, which regulates fatty acid synthase and other lipogenic enzymes [20]. Inhibition of AMPK in hepatocytes may contribute to the lipogenic actions of endocannabinoids [66]. CB1-/- mice were protected against the development of liver steatosis and fibrosis when fed a high-fat diet because important genes of lipogenesis (e.g. fatty acid synthase, acetyl-CoA carboxylase-1) were down-regulated in hepatocytes of CB1-/- mice [20]. The same result was obtained by treating obese Zucker rats with rimonabant [72]. In this study, amelioration of hepatomegaly, liver steatosis, and hepatocyte damage was associated with decreased local and circulating tumor necrosis factor $\alpha$ levels, increased adiponectin levels, and improved lipid profile of the animals. Importantly, pair-feeding in a second group of untreated obese Zucker rats prompted few hepatoprotective ef-

fects, again suggesting that not reduced caloric intake per se but local peripheral mechanisms are operational for the metabolic effects of CB1 blockade.

Liver cirrhosis in humans was accompanied by strongly enhanced CB1 receptor gene expression [73], whereas in mice with toxic liver disease and resulting cirrhosis both anandamide and 2-AG tissue concentrations were increased 3- to 6-fold [74]. Furthermore, genetic inactivation or blockade of CB1 receptors decreased fibrotic activity of hepatic myofibroblasts in animal models of toxic liver damage. A possible antifibrotic mechanism of CB1 blockade in this study was decreased hepatic expression of transforming growth factor $\beta$ in treated and knockout mice. Concurrent anti-inflammatory effects of hepatic $\mathrm{CB} 2$ receptor stimulation may also have contributed to the effects of CB1 receptor blockade [73].

\section{The Endocannabinoid System in the Pancreas}

The data on the ECS in the pancreas are preliminary at present, limited in number and contradictory, most likely because of species differences, the use of cell lines, and the quality of antibodies used (as discussed before). Pancreatic islets express ECS genes and synthesize endocannabinoids. Formation of 2-AG was stimulated by glucose and insulin, and inhibited by leptin in the RIN-m5F rat insulinoma $\beta$-cell line [38]. In mouse islets, CB1 expression was restricted to pancreatic $\alpha$-cells that produce glucagon, whereas $\mathrm{CB} 2$ was detected in $\alpha$ - and $\beta$-cells. Anandamide and 2-AG via $\mathrm{CB} 2$ receptors reduced $\mathrm{Ca}^{2+}$ oscillations and insulin secretion in mouse islets [75]. In contrast to mouse islets, the rat insulinoma $\beta$-cell line expressed both cannabinoid receptors [38]. In these cells, cannabinoid receptor stimulation increased intracellular calcium availability and in- 
sulin secretion $[38,76]$. In rat islets, $\mathrm{CB} 1$ and $\mathrm{CB} 2$ were expressed on both $\alpha$ - and $\beta$-cells [77]. Activation of CB1 receptors in wild-type rats decreased glucose tolerance [78]. Furthermore, administration of CB2 agonists improved glucose tolerance and treatment with a CB2 antagonist also decreased glucose tolerance [77]. As concomitant treatment with a CB1 antagonists also improved glucose tolerance, the authors hypothesized that this effect is indirectly mediated by enhanced CB2 receptor signalling. Recent data in obese Zucker rats suggested that rimonabant treatment preserves pancreatic islet integrity and $\beta$-cell mass in this model of type 2 diabetes [25]. Together with metabolic and hemodynamic improvements, and a clear amelioration of renal pathology (decreased sclerosis and albuminuria), rimonabant treatment was associated with a strong decrease of mortality in the obese Zucker rat model.

\section{The Endocannabinoid System in Skeletal Muscle}

Only few reports investigated the ECS in skeletal muscle physiology. CB1 expression was found to be the same in myotubes grown in vitro from a small number of lean and obese human donors [79]. Both FAAH and MGL are also expressed in minor quantities in human skeletal muscle biopsies (unpublished data). AMP-kinase did not mediate the insulin-desensitizing effect of cannabinoids in rat skeletal muscle [66], but blockade of CB1 receptors in human skeletal muscle myotubes enhanced AMP-kinase mRNA expression [79]. High-fat feeding enhanced CB1 expression in skeletal muscle of mice. Treating genetically obese mice with rimonabant increased glucose uptake and oxygen consumption in the soleus muscle, which may lead to increased thermogenesis and enhanced insulin sensitivity [55]. In line with these observations, we reported a correlation between increased levels of circulating 2-AG and decreased insulin sensitivity during euglycemichyperinsulinemic clamp in 60 middle-aged human subjects [21]. Increased glucose and insulin responses to an oral glucose load in men with the highest circulating 2-AG levels were also described [22].

\section{Endocannabinoids and Gastrointestinal Hormones}

The influence of endocannabinoids on feeding behavior can to some extent also be explained by peripheral interactions with gastrointestinal hormones. CB1 receptors and receptors for gastrointestinal hormones such as cholecystokinin (CCK), ghrelin, and orexins are co-localized on vagal nerve terminals projecting from the gastrointestinal tract to the nucleus of the solitary tract $[80,81]$. CB1 receptors are up-regulated by fasting and down-regulated by feeding, and this reaction was blocked by CCK antagonists. Thus, the anorexigenic action of CCK may in part mediated by down-regulation of orexigenic CB1 receptors. Activation of ghrelin receptors also prevents the down-regulation of vagal CB1 receptors [80, 81]. Vice versa, the response of circulating ghrelin to fasting was diminished by rimonabant, suggesting that $\mathrm{CB} 1$ receptors are directly involved in ghrelin secretion. In contrast, glucagon-like peptide 1 was not influenced by rimonabant in these studies [82]. In the brain, the orexigenic effects of centrally administered ghrelin were abolished by rimonabant. Thus, ghrelin possibly increased endocannabinoid production in the hypothalamus in this study [83]. Other interactions between the ECS and gastrointestinal hormones, functions and diseases have been described, but are outside of the focus of this review [84].

\section{Conclusion: Many Questions - Few Answers}

The marketing of rimonabant was an important step forward because for the first time in nearly a decade a drug with weight-reducing actions successfully passed clinical development. Furthermore, rimonabant as a tool broadened the view on metabolic regulation and the regulation of food intake by introducing the ECS to metabolic research. However, several open questions remain. First, a strong discussion of the risk profile of the drug had started. At present this discussion is only based on the published data from the RIO trials, and no new insights have been added, but blockade of this widespread system clearly warrants a high level of pharmacovigilance. Given the many promising peripheral effects of CB1 receptor blockade, the development of antagonists not entering the central nervous system may offer an important improvement in terms of safety because, then, side effects caused by blockade of central CB1 receptors should be minimized. Several drugs affecting the ECS are currently in development, e.g. FAAH inhibitors, but most of them will directly or indirectly activate cannabinoid receptors in order to modulate chronic inflammation and pain disorders. Again, the development of drugs with only peripheral actions to avoid central side effects is preferred $[85,86]$.

Second, the peripheral metabolic effects described in this review (fig. 1) were extracted from a rather limited number of studies and were mostly obtained in animal models and cellular systems that are far away from the pathophysiology of human metabolic disorders and human obesity. Studies need to be done that address the effects of rimonabant on food intake in humans and on energy expenditure in humans and animals. The pharmacology of the ECS as such is complex, and the pharmacology of compounds currently available to target the ECS is even more complex. Thus, some of the possible endocannabinoid effects are only deduced from data of cannabinoid receptor blockade studies. In conclusion, several inconsistencies and uncertainties must currently be considered when the peripheral metabolic actions of the ECS are discussed. Hopefully, the development of newer drugs acting on the ECS will help to better define the promising peripheral metabolic effects of CB1 receptor blockade. 


\section{References}

1 Gaoni Y, Mechoulam R: Isolation, structure, and partial synthesis of an active constituent of hashish. J Am Chem Soc 1964;86:1646-1647.

2 Devane WA, Dysarz FA III, Johnson MR, Melvin LS, Howlett AC: Determination and characterization of a cannabinoid receptor in rat brain. Mol Pharmacol 1988;34:605-613.

3 Matsuda LA, Lolait SJ, Brownstein MJ, Young AC, Bonner TI: Structure of a cannabinoid receptor and functional expression of the cloned cDNA. Nature 1990;346:561-564.

4 Gerard CM, Mollereau C, Vassart G, Parmentier M: Molecular cloning of a human cannabinoid receptor which is also expressed in testis. Biochem J 1991;279:129-134.

$\checkmark 5$ Devane WA, Hanus L, Breuer A, Pertwee RG, Stevenson LA, Griffin G, Gibson D, Mandelbaum A, Etinger A, Mechoulam R: Isolation and structure of a brain constituent that binds to the cannabinoid receptor. Science 1992;258:1946-1949.

6 Munro S, Thomas KL, Abu-Shaar M: Molecular characterization of a peripheral receptor for cannabinoids. Nature 1993;365:61-65.

7 Rinaldi-Carmona M, Barth F, Heaulme M, Shire D, Calandra B, Congy C, Martinez S, Maruani J, Neliat G, Caput D: SR141716A, a potent and selective antagonist of the brain cannabinoid receptor. FEBS Lett 1994;350:240-244.

8 Mechoulam R, Ben-Shabat S, Hanus L, Ligumsky M, Kaminski NE, Schatz AR, Gopher A, Almog S, Martin BR, Compton DR: Identification of an endogenous 2-monoglyceride, present in canine gut, that binds to cannabinoid receptors. Biochem Pharmacol 1995;50:83-90.

$\checkmark$ Cravatt BF, Giang DK, Mayfield SP, Boger DL, Lerner RA, Gilula NB: Molecular characterization of an enzyme that degrades neuromodulatory fattyacid amides. Nature 1996;384:83-87.

10 Colombo G, Agabio R, Diaz G, Lobina C, Reali R, Gessa GL: Appetite suppression and weight loss after the cannabinoid antagonist SR 141716. Life Sci 1998;63:L113-L117.

11 Ledent C, Valverde O, Cossu G, Petitet F, Aubert JF, Beslot F, Bohme GA, Imperato A, Pedrazzini T, Roques BP, Vassart G, Fratta W, Parmentier M: Unresponsiveness to cannabinoids and reduced addictive effects of opiates in CB1 receptor knockout mice. Science 1999;283:401-404.

12 Zimmer A, Zimmer AM, Hohmann AG, Herkenham M, Bonner TI: Increased mortality, hypoactivity, and hypoalgesia in cannabinoid CB1 receptor knockout mice. Proc Natl Acad Sci U S A 1999; 96:5780-5785.

13 Wilson RI, Nicoll RA: Endogenous cannabinoids mediate retrograde signalling at hippocampal synapses. Nature 2001;410:588-592.

14 Cota D, Marsicano G, Tschöp M, Grubler Y, Flachskamm C, Schubert M, Auer D, Yassouridis A Thöne-Reineke C, Ortmann S, Tomassoni F, Cervino C, Nisoli E, Linthorst AC, Pasquali R, Lutz B, Stalla GK, Pagotto U: The endogenous cannabinoid system affects energy balance via central orexigenic drive and peripheral lipogenesis. J Clin Invest 2003;112:423-431.

15 Bensaid M, Gary-Bobo M, Esclangon A, Maffrand JP, Le Fur G, Oury-Donat F, Soubrie P: The cannabinoid CB1 receptor antagonist SR141716 increases Acrp30 mRNA expression in adipose tissue of obese fa/fa rats and in cultured adipocyte cells. Mol Pharmacol 2003;63:908-914.
16 Bisogno T, Howell F, Williams G, Minassi A, Cascio MG, Ligresti A, Matias I, Schiano-Moriello A, Paul P, Williams EJ, Gangadharan U, Hobbs C, Di Marzo V, Doherty P: Cloning of the first sn1-DAG lipases points to the spatial and temporal regulation of endocannabinoid signaling in the brain. J Cell Biol 2003;163:463-468.

17 Okamoto Y, Morishita J, Tsuboi K, Tonai T, Ueda $\mathrm{N}$ : Molecular characterization of a phospholipase D generating anandamide and its congeners. J Biol Chem 2004;279:5298-5305.

18 Van Gaal LF, Rissanen AM, Scheen AJ, Ziegler O, Rössner S: Effects of the cannabinoid-1 receptor blocker rimonabant on weight reduction and cardiovascular risk factors in overweight patients: 1year experience from the RIO-Europe study. Lancet 2005;365:1389-1397.

19 Després JP, Golay A, Sjöström L: Effects of rimonabant on metabolic risk factors in overweight patients with dyslipidemia. N Engl J Med 2005;353: 2121-2134.

20 Osei-Hyiaman D, Depetrillo M, Pacher P, Liu J, Radaeva S, Batkai S, Harvey-White J, Mackie K, Offertaler L, Wang L, Kunos G: Endocannabinoid activation at hepatic $\mathrm{CB}(1)$ receptors stimulates fatty acid synthesis and contributes to diet-induced obesity. J Clin Invest 2005;115:1298-1305.

21 Blüher M, Engeli S, Klöting N, Berndt J, Fasshauer M, Batkai S, Pacher P, Schön MR, Jordan J, Stumvoll M: Dysregulation of the peripheral and adipose tissue endocannabinoid system in human abdominal obesity. Diabetes 2006;55:3053-3060.

22 Côté M, Matias I, Lemieux I, Petrosino S, Almeras N, Després JP, Di Marzo V: Circulating endocannabinoid levels, abdominal adiposity and related cardiometabolic risk factors in obese men. Int $\mathbf{J}$ Obes 2007;31:692-699.

23 Scheen AJ, Finer N, Hollander P, Jensen MD, Van Gaal LF: Efficacy and tolerability of rimonabant in overweight or obese patients with type 2 diabetes: a randomised controlled study. Lancet 2006; 368:1660-1672.

24 Pi-Sunyer FX, Aronne LJ, Heshmati HM, Devin J, Rosenstock J: Effect of rimonabant, a cannabinoid1 receptor blocker, on weight and cardiometabolic risk factors in overweight or obese patients: RIONorth America: a randomized controlled trial. JAMA 2006;295:761-775.

25 Janiak P, Poirier B, Bidouard JP, Cadrouvele C, Pierre F, Gouraud L, Barbosa I, Dedio J, Maffrand JP, Le Fur G, O'Connor S, Herbert JM: Blockade of cannabinoid CB1 receptors improves renal function, metabolic profile, and increased survival of obese Zucker rats. Kidney Int 2007;72:1345-1357.

26 Howlett AC, Barth F, Bonner TI, Cabral G, Casellas P, Devane WA, Felder CC, Herkenham M, Mackie K, Martin BR, Mechoulam R, Pertwee RG: International Union of Pharmacology. XXVII. Classification of cannabinoid receptors. Pharmacol Rev 2002;54:161-202.

27 Van Sickle MD, Duncan M, Kingsley PJ, Mouihate A, Urbani P, Mackie K, Stella N, Makriyannis A, Piomelli D, Davison JS, Marnett LJ, Di Marzo V, Pittman QJ, Patel KD, Sharkey KA: Identification and functional characterization of brainstem cannabinoid CB2 receptors. Science 2005;310: 329-332.

28 Pacher P, Batkai S, Kunos G: The endocannabinoid system as an emerging target of pharmacotherapy. Pharmacol Rev 2006;58:389-462.

29 Di Marzo V, Bifulco M, De Petrocellis L: The endocannabinoid system and its therapeutic exploitation. Nat Rev Drug Discov 2004:3:771-784.
30 Pagotto U, Marsicano G, Cota D, Lutz B, Pasquali $\mathrm{R}$ : The emerging role of the endocannabinoid system in endocrine regulation and energy balance. Endocr Rev 2006;27:73-100.

31 Piomelli D: The molecular logic of endocannabinoid signalling. Nat Rev Neurosci 2003;4:873-884.

32 Wagner JA, Varga K, Ellis EF, Rzigalinski BA, Martin BR, Kunos G: Activation of peripheral CB1 cannabinoid receptors in haemorrhagic shock. Nature 1997;390:518-521.

33 Batkai S, Jarai Z, Wagner JA, Goparaju SK, Varga K, Liu J, Wang L, Mirshahi F, Khanolkar AD, Makriyannis A, Urbaschek R, Garcia N Jr., Sanyal AJ, Kunos G: Endocannabinoids acting at vascular CB1 receptors mediate the vasodilated state in advanced liver cirrhosis. Nat Med 2001;7:827-832.

34 Batkai S, Osei-Hyiaman D, Pan H, El-Assal O, Rajesh M, Mukhopadhyay P, Hong F, Harvey-White J, Jafri A, Hasko G, Huffman JW, Gao B, Kunos G, Pacher P: Cannabinoid-2 receptor mediates protection against hepatic ischemia/reperfusion injury. FASEB J 2007;21:1788-1800.

35 Mukhopadhyay P, Batkai S, Rajesh M, Czifra N, Harvey-White J, Hasko G, Zsengeller Z, Gerard NP, Liaudet L, Kunos G, Pacher P: Pharmacological inhibition of CB1 cannabinoid receptor protects against doxorubicin-induced cardiotoxicity. J Am Coll Cardiol 2007;50:528-536.

36 Batkai S, Rajesh M, Mukhopadhyay P, Hasko G, Liaudet L, Cravatt BF, Csiszar A, Ungvari Z, Pacher P: Decreased age-related cardiac dysfunction, myocardial nitrative stress, inflammatory gene expression, and apoptosis in mice lacking fatty acid amide hydrolase. Am J Physiol Heart Circ Physiol 2007; 293:H909-H918.

37 Steffens S, Veillard NR, Arnaud C, Pelli G, Burger F, Staub C, Karsak M, Zimmer A, Frossard JL, Mach F: Low dose oral cannabinoid therapy reduces progression of atherosclerosis in mice. Nature 2005;434:782-786.

38 Matias I, Gonthier MP, Orlando P, Martiadis V, De Petrocellis L, Cervino C, Petrosino S, Hoareau L, Festy F, Pasquali R, Roche R, Maj M, Pagotto U, Monteleone P, Di Marzo V: Regulation, function, and dysregulation of endocannabinoids in models of adipose and beta-pancreatic cells and in obesity and hyperglycemia. J Clin Endocrinol Metab 2006; 91:3171-3180.

39 Engeli S, Böhnke J, Feldpausch M, Gorzelniak K, Janke J, Batkai S, Pacher P, Harvey-White J, Luft FC, Sharma AM, Jordan J: Activation of the peripheral endocannabinoid system in human obesity. Diabetes 2005;54:2838-2843.

40 Xie S, Furjanic MA, Ferrara JJ, McAndrew NR, Ardino EL, Ngondara A, Bernstein Y, Thomas KJ, Kim E, Walker JM, Nagar S, Ward SJ, Raffa RB: The endocannabinoid system and rimonabant: a new drug with a novel mechanism of action involving cannabinoid CB1 receptor antagonism - or inverse agonism - as potential obesity treatment and other therapeutic use. J Clin Pharm Ther 2007;32: 209-231.

41 Rucker D, Padwal R, Li SK, Curioni C, Lau DC: Long term pharmacotherapy for obesity and overweight: updated meta-analysis. BMJ 2007;335: 1194-1199.

42 Berry EM, Mechoulam R: Tetrahydrocannabinol and endocannabinoids in feeding and appetite. Pharmacol Ther 2002;95:185-190.

43 Jamshidi N, Taylor DA: Anandamide administration into the ventromedial hypothalamus stimulates appetite in rats. Br J Pharmacol 2001;134:11511154 
44 Williams CM, Kirkham TC: Anandamide induces overeating: mediation by central cannabinoid (CB1) receptors. Psychopharmacology (Berl) 1999; 143:315-317.

-45 Morton GJ, Cummings DE, Baskin DG, Barsh GS Schwartz MW: Central nervous system control of food intake and body weight. Nature 2006;443: 289-295.

46 Burns HD, Van Laere K, Sanabria-Bohorquez S, Hamill TG, Bormans G, Eng WS, Gibson R, Ryan C, Connolly B, Patel S, Krause S, Vanko A, Van HA, Dupont P, De Lepeleire I, Rothenberg P, Stoch SA, Cote J, Hagmann WK, Jewell JP, Lin LS, Liu P, Goulet MT, Gottesdiener K, Wagner JA, de Hoon J, Mortelmans L, Fong TM, Hargreaves RJ: [18F]MK 9470, a positron emission tomography (PET) tracer for in vivo human PET brain imaging of the cannabinoid-1 receptor. Proc Natl Acad Sci U S A 2007;104:9800-9805.

47 Wittmann G, Deli L, Kallo I, Hrabovszky E, Watanabe M, Liposits Z, Fekete C: Distribution of type 1 cannabinoid receptor (CB1)-immunoreactive axons in the mouse hypothalamus. J Comp Neurol 2007:503:270-279.

48 Harrold JA, Williams G: The cannabinoid system: a role in both the homeostatic and hedonic control of eating? Br J Nutr 2003;90:729-734.

49 Di Marzo V, Goparaju SK, Wang L, Liu J, Batkai S, Jarai Z, Fezza F, Miura GI, Palmiter RD, Sugiura T, Kunos G: Leptin-regulated endocannabinoids are involved in maintaining food intake. Nature 2001;410:822-825.

50 Jo YH, Chen YJ, Chua SC Jr, Talmage DA, Role LW: Integration of endocannabinoid and leptin signaling in an appetite-related neural circuit. Neuron 2005;48:1055-1066.

51 Ravinet Trillou C, Delgorge C, Menet C, Arnone M, Soubrie P: CB1 cannabinoid receptor knockout in mice leads to leanness, resistance to diet-induced obesity and enhanced leptin sensitivity. Int J Obes 2004;28:640-648.

52 Osei-Hyiaman D, Depetrillo M, Harvey-White J, Bannon AW, Cravatt BF, Kuhar MJ, Mackie K, Palkovits M, Kunos G: Cocaine- and amphetaminerelated transcript is involved in the orexigenic effect of endogenous anandamide. Neuroendocrinology 2005;81:273-282.

53 Ravinet Trillou C, Arnone M, Delgorge C, Gonalons N, Keane P, Maffrand JP, Soubrie P: Antiobesity effect of SR141716, a CB1 receptor antagonist, in diet-induced obese mice. Am J Physiol Regul Integr Comp Physiol 2003;284:R345-R353.

54 Jbilo O, Ravinet Trillou C, Arnone M, Buisson I, Bribes E, Peleraux A, Penarier G, Soubrie P, Le Fur G, Galiegue S, Casellas P: The CB1 receptor antagonist rimonabant reverses the diet-induced obesity phenotype through the regulation of lipolysis and energy balance. FASEB J 2005;19:1567-1569.

55 Liu YL, Connoley IP, Wilson CA, Stock MJ: Effects of the cannabinoid $\mathrm{CB} 1$ receptor antagonist SR141716 on oxygen consumption and soleus muscle glucose uptake in Lep(ob)/Lep(ob) mice. Int J Obes 2005;29:183-187.

56 Spoto B, Fezza F, Parlongo G, Battista N, Sgro' E, Gasperi V, Zoccali C, Maccarrone M: Human adipose tissue binds and metabolizes the endocannabinoids anandamide and 2-arachidonoylglycerol. Biochimie 2006;88:1889-1897.

57 Gonthier MP, Hoareau L, Festy F, Matias I, Valenti M, Bes-Houtmann S, Rouch C, Robert-Da SC, Chesne S, Lefebvre d'Hellencourt C, Cesari M, Di Marzo V, Roche R: Identification of endocannabinoids and related compounds in human fat cells. Obesity 2007; $15: 837-845$.
58 Pagano C, Pilon C, Calcagno A, Urbanet R, Rossato M, Milan G, Bianchi K, Rizzuto R, Bernante P, Federspil G, Vettor G: The endogenous cannabinoid system stimulates glucose uptake in human fat cells via PI3-kinase and calcium-dependent mechanisms. J Clin Endocrinol Metab 2007; 92:4810-4819.

59 Karlsson M, Contreras JA, Hellman U, Tornqvist H, Holm C: cDNA cloning, tissue distribution, and identification of the catalytic triad of monoglyceride lipase. Evolutionary relationship to esterases, lysophospholipases, and haloperoxidases. J Biol Chem 1997;272:27218-27223.

60 Roche R, Hoareau L, Bes-Houtmann S, Gonthier MP, Laborde C, Baron JF, Haffaf Y, Cesari M, Festy F: Presence of the cannabinoid receptors, $\mathrm{CB} 1$ and $\mathrm{CB} 2$, in human omental and subcutaneous adipocytes. Histochem Cell Biol 2006;126:177-187.

61 Gasperi V, Fezza F, Pasquariello N, Bari M, Oddi S, Agro AF, Maccarrone M: Endocannabinoids in adipocytes during differentiation and their role in glucose uptake. Cell Mol Life Sci 2007;64:219-229.

62 Zeyda M, Stulnig TM: Adipose tissue macrophages. Immunol Lett 2007;112:61-67.

63 Yan ZC, Liu DY, Zhang LL, Shen CY, Ma QL, Cao TB, Wang LJ, Nie H, Zidek W, Tepel M, Zhu ZM: Exercise reduces adipose tissue via cannabinoid receptor type 1 which is regulated by peroxisome proliferator-activated receptor-delta. Biochem Biophys Res Commun 2007;354:427-433.

64 Bouaboula M, Hilairet S, Marchand J, Fajas L, Le Fur G, Casellas P: Anandamide induced PPAR $\gamma$ transcriptional activation and 3T3-L1 preadipocyte differentiation. Eur J Pharmacol 2005;517:174-181.

65 Burstein S: PPAR-gamma: a nuclear receptor with affinity for cannabinoids. Life Sci 2005;77: 1674-1684.

66 Kola B, Hubina E, Tucci SA, Kirkham TC, Garcia EA, Mitchell SE, Williams LM, Hawley SA, Hardie DG, Grossman AB, Korbonits M: Cannabinoids and ghrelin have both central and peripheral metabolic and cardiac effects via AMP-activated protein kinase. J Biol Chem 2005;280:25196-25201.

67 Gary-Bobo M, Elachouri G, Scatton B, Le Fur G, Oury-Donat F, Bensaid M: The cannabinoid CB1 receptor antagonist rimonabant (SR141716) inhibits cell proliferation and increases markers of adipocyte maturation in cultured mouse 3T3 F442A preadipocytes. Mol Pharmacol 2006;69: 471-478.

68 Löfgren P, Sjölin E, Wahlen K, Hoffstedt J: Human adipose tissue cannabinoid receptor 1 gene expression is not related to fat cell function or adiponectin level. J Clin Endocrinol Metab 2007;92:1555-1559.

69 Thornton-Jones ZD, Kennett GA, Benwell KR, Revell DF, Misra A, Sellwood DM, Vickers SP, Clifton PG: The cannabinoid CB1 receptor inverse agonist, rimonabant, modifies body weight and adiponectin function in diet-induced obese rats as a consequence of reduced food intake. Pharmacol Biochem Behav 2006;84:353-359.

70 Perwitz N, Fasshauer M, Klein J: Cannabinoid receptor signaling directly inhibits thermogenesis and alters expression of adiponectin and visfatin. Horm Metab Res 2006;38:356-358.

71 Maccarrone M, Fride E, Bisogno T, Bari M, Cascio MG, Battista N, Finazzi AA, Suris R, Mechoulam R, Di Marzo V: Up-regulation of the endocannabinoid system in the uterus of leptin knockout (ob/ob) mice and implications for fertility. Mol Hum Reprod 2005;11:21-28.
72 Gary-Bobo M, Elachouri G, Gallas JF, Janiak P, Marini P, Ravinet Trillou C, Chabbert M, Cruccioli N, Pfersdorff C, Roque C, Arnone M, Croci T, Soubrie P, Oury-Donat F, Maffrand JP, Scatton B, Lacheretz F, Le Fur G, Herbert JM, Bensaid M: Rimonabant reduces obesity-associated hepatic steatosis and features of metabolic syndrome in obese Zucker fa/fa rats. Hepatology 2007;46: 122-129.

73 Teixeira-Clerc F, Julien B, Grenard P, Tran VN, Deveaux V, Li L, Serriere-Lanneau V, Ledent C, Mallat A, Lotersztajn S: CB1 cannabinoid receptor antagonism: a new strategy for the treatment of liver fibrosis. Nat Med 2006;12:671-676.

74 Batkai S, Mukhopadhyay P, Harvey-White J, Kechrid R, Pacher P, Kunos G: Endocannabinoids acting at $\mathrm{CB} 1$ receptors mediate the cardiac contractile dysfunction in vivo in cirrhotic rats. Am J Physiol Heart Circ Physiol 2007;293:H1689-H1695.

75 Juan-Pico P, Fuentes E, Bermudez-Silva FJ, Javier Diaz-Molina F, Ripoll C, Rodriguez de Fonseca F, Nadal A: Cannabinoid receptors regulate $\mathrm{Ca}(2+)$ signals and insulin secretion in pancreatic beta-cell. Cell Calcium 2006;39:155-162.

76 De Petrocellis L, Marini P, Matias I, Schiano Moriello A, Starowicz K, Cristino L, Nigam S, Di Marzo V: Mechanisms for the coupling of cannabinoids receptors to intracellular calcium mobilization in rat insulinoma $\beta$-cells. Exp Cell Res 2007; 313:2993-3004.

77 Bermudez-Silva FJ, Sanchez-Vera I, Suarez J, Serrano A, Fuentes E, Juan-Pico P, Nadal A, Rodriguez de Fonseca F: Role of cannabinoid CB2 receptors in glucose homeostasis in rats. Eur J Pharmacol 2007:565:207-211.

78 Bermudez-Silva FJ, Serrano A, Diaz-Molina FJ, Sanchez Vera I, Juan-Pico P, Nadal A, Fuentes E, Rodriguez de Fonseca F: Activation of cannabinoid CB1 receptors induces glucose intolerance in rats. Eur J Pharmacol 2006;531:282-284

79 Cavuoto P, McAinch AJ, Hatzinikolas G, CameronSmith D, Wittert GA: Effects of cannabinoid receptors on skeletal muscle oxidative pathways. $\mathrm{Mol}$ Cell Endocrinol 2007;267:63-69.

80 Burdyga G, Lal S, Varro A, Dimaline R, Thompson DG, Dockray GJ: Expression of cannabinoid CB1 receptors by vagal afferent neurons is inhibited by cholecystokinin. J Neurosci 2004;24:2708-2715.

81. Burdyga G, Varro A, Dimaline R, Thompson DG, Dockray GJ: Ghrelin receptors in rat and human nodose ganglia: putative role in regulating CB-1 and $\mathrm{MCH}$ receptor abundance. Am J Physio Gastrointest Liver Physiol 2006;290:G1289-G1297.

82. Cani PD, Montoya ML, Neyrinck AM, Delzenne NM, Lambert DM: Potential modulation of plasma ghrelin and glucagon-like peptide- 1 by anorexigenic cannabinoid compounds, SR141716A (rimonabant) and oleoylethanolamide. Br J Nutr 2004;92: 757-761.

83 Tucci SA, Rogers EK, Korbonits M, Kirkham TC: The cannabinoid CB1 receptor antagonist SR141716 blocks the orexigenic effects of intrahypothalamic ghrelin. Br J Pharmacol 2004;143: 520-523.

84 Storr MA, Sharkey KA: The endocannabinoid system and gut-brain signalling. Curr Opin Pharmacol 2007:7:575-582.

85. Saario SM, Laitinen JT: Therapeutic potential of endocannabinoid-hydrolysing enzyme inhibitors. Basic Clin Pharmacol Toxicol 2007;101:287-293.

86. Fowler CJ: The pharmacology of the cannabinoid system - a question of efficacy and selectivity. Mol Neurobiol 2007;36:15-25. 